\title{
Social housing in a suburban context: A bearer of peri-urban diversity?
}

In recent years, French urban policies have demanded reflection on the possible relations and intersections between two emblematic, and almost antithetical, forms of housing: collective social housing and suburban single-family housing. There are two main laws in place that encourage opposite dynamics in the housing market: on the one hand, the Solidarity and Urban Renovation Act adopted in 2000 promotes social housing construction, obliging municipalities to achieve a certain quota. On the other hand, the Housing and Renewed Urbanism Act adopted in 2014 facilitates private housing production to limit urban sprawl through suburban densification. These opposite planning approaches leave local governments responsible for enforcing complicated policies of question- able feasibility. This article presents the main social and political concepts used in France today to promote social housing: the right to housing and, most importantly for suburbs, the social diversity of neighbourhoods. Subsequently, the relevance of social diversity for the suburbs is discussed. Certain social housing projects that have been successfully implemented in suburban neighbourhoods are examined. Finally, this article opens a discussion on possible methods for resolving the opposition between the dynamics of social housing construction and private housing densification processes in the suburbs.

Keywords: urban policies, social housing, social diversity, suburbs, single-family housing 


\section{Introduction}

Collective social housing and suburban single-family housing are two characteristic forms of housing in recent French history in urban and peri-urban areas, and also in political and academic discourse concerning housing and the urban environment in general. They are rarely associated and almost never imagined as coexisting; the social housing blocks, the grands ensembles of Modernism, and the individual suburban residences inspired by New Urbanism often serve as counterexamples of one another (Lelévrier, 2014). However, recent French urban policies demand reflection on the possible relations and intersections between them. These reflections are imposed by and at the same time inscribed in a specific legal and policy framework provided especially by two laws: the Solidarity and Urban Renovation Act (Fr. Solidarité et renouvellement urbain, SRU) adopted in 2000 and the Housing and Renewed Urbanism Act (Fr. Logement et un urbanisme rénové, ALUR) adopted in 2014. These two laws have been very influential for discussions of social housing and suburban housing.

First, a short bibliographic overview is provided to define the subject matter. Then the French legal framework and the urban policies it entails are examined. From this examination, a hypothesis is formed: the French suburban context currently has two opposing housing policies due to the SRU and ALUR. Opposing dynamics occur between the application of policies imposing a specific percentage of social housing within the total housing stock of each municipality, and the application of policies that facilitate suburban densification (and therefore the multiplication of private housing). Subsequently, and in order to better understand this condition, the various policies that promote social housing in France today are examined. Social diversity is a central concept for encouraging social housing construction, and it is therefore questioned in an effort to define the concept's pertinence to suburban areas. The social characteristics of suburban France are therefore also examined. Finally, certain examples of social housing construction in French suburbs are presented. These examples constitute the basis for a discussion on possible ways to resolve the antagonistic policies identified, and proposals are offered for the systematic construction of social housing in suburbs.

\section{The context of suburbs}

This article begins by reviewing statistical, legal, and bibliographical sources, focusing on the French example. Two terms used in this article must be defined. Peri-urban area refers to location and is understood in relation to an urban centre as its periphery usually forming concentric circles around it (Dodier \& Cailly, 2008), whereas suburb is defined mostly morphologically, as a territory where single-family housing proliferates (Duany et al., 2010). Therefore, suburban fabric can be found in peri-urban areas, and peri-urban areas may largely consist of suburban fabric; however, the two do not necessarily coincide. However, it is true that they are two characteristics (one locational, one morphological) that very often coexist, and they tend to be used interchangeably in French sources.

The question of suburbs is a complex one, and its widespread, ever-expanding presence throughout the world has been a subject of international academic discussion for years. In the United States (often considered the exemplar country of the application of the suburban model), important publications include those by Jackson (Crabgrass Frontier: The Suburbanization of the United States, 1985) and Fishman (Bourgeois Utopias: The Rise and Fall of Suburbia, in 1987), who study the historical socioeconomic roots of suburbs and identify the importance of private property and home ownership, as much as they identify characteristics such as low population density and a dominant residential status. In Italy the concept was first explored by Indovina, who referred to the citta difussa 'diffused city' in 1990, and Secchi (who observed similar phenomena, extending them to the European scale), both noting the expanding scale of urban spatial organization mostly due to the dispersion of the residential function (Indovina, 1990; Crysler et al., 2012). Similarly, observing the Ruhr region in Germany, Sieverts explores the concept of what he terms the Zwischenstadt 'in-between cities' in his 1997 book, recognizing the spatial, economic, and historical characteristics of a new form of urbanization at a regional scale that is neither urban nor rural (Sieverts, 2003; Charmes, 2015b). The same year in France, Dubois-Taine and Chalas (1997) published on the concept of the ville émergente 'emerging city', also discussing its ambiguous character between urban and rural, and city and nature, and noting the seminal role of the suburban house (Charmes, 2015a).

It is interesting to note that in the 2000s, and with the environmental discourses of sustainable urbanization being established, criticism of the suburbs began to focus around their fundamental contribution to urban sprawl. In Suburban $\mathrm{Na}^{-}$ tion: The Rise of Sprawl and the Decline of the American Dream, Duany et al. (2010) focus on the urban and architectural characteristics most prominent in suburban sprawl (e.g., subdivisions and roads), contrasting them with the traditional dense urban centre (in terms of centrality, walkability, and mixed use) and highlighting their harmful environmental effects. In France, similar criticism arises, with the waste of agricultural and natural land, the extended soil sealing, and the dependency on (and intensification of) car use being some of the focal points studied by the national organization of archi- 
tectural and urban research and experimentation, known as PUCA (2015a, 2015b, 2015c). Other criticism in France has to do with the socio-political characteristics of the suburban population, criticizing the lack of social diversity (Donzelot \& Epstein, 2009) or its right-wing tendencies (Lévy, 2007). Both environmental and social concerns are embodied in laws established by the French state, and it is interesting to examine them.

\section{The legal and urban policy framework}

Concerning environmental issues, the laws Grenelles I (law no. 2009-967 of 3 August 2009) and Grenelles II (law no. 2010788 of 12 July 2010), followed most importantly by their successor law, ALUR (law no. 2014-366 of 24 March 2014), aim at limiting urban sprawl and the consumption of natural and agricultural space by facilitating densification processes. The urban policies that followed make it very difficult for local governments to open new zones for urbanization and make evaluation of densification possibilities obligatory at the local level. In addition, plot subdivision processes are facilitated: the previous plot / construction ratio is abandoned for a method that allows a higher occupancy index, and the municipalities' previous right to define the minimum size of a constructible plot is withdrawn (Ministère du Logement ..., 2014). These developments particularly concern peri-urban zones and specifically suburban territories. As established by many extensive research programmes in France, these large territories of patchy urban fabric and low density, spreading around and between urban centres - most commonly referred to as périurbain 'peri-urban' and pavillonnaire 'suburban' in French literature - seem to have genuine potential for densification processes (Hanrot, 2014; Bonnet, 2016).

On the other hand, an emblematic example of social concerns expressed through urban policies is Article 55 of the SRU, which prescribes a quota of at least $20 \%$ of social housing within the total housing stock of municipalities with more than 3,500 residents (1,500 for Île-de-France). It establishes a system of penalization with annual and triennial fines calculated in relation to the level of social housing deficiency of each municipality (law no. 2000-1208 of 13 December 2000). The Duflot Law of 2013, reinforces these requirements, raising the percentage of social housing demanded to $25 \%$ for most cases (certain municipalities are exempted from the new quota) and increasing the level of fines (law no. 2013-61 of 18 January 2013). In France, out of 36,685 municipalities, only $8.5 \%$ have a population over 3,500 (and are therefore affected by these laws). However, these municipalities include $67.6 \%$ of the country's population (INSEE, 2017). In the national survey of 2017 , out of the 1,997 municipalities concerned, 1,222 of them did not respect their obligations with regard to social housing stock and were subjected to fines totalling EUR 76.8 million, which in turn is used to finance the social housing sector (Ministère de la Cohésion ..., 2018).

It is therefore possible to identify two opposing housing dynamics in the suburbs. On the one hand, there is the dynamic of private housing through plot subdivision facilitated by the ALUR. On the other hand, there is the dynamic of social housing, a municipal necessity prescribed by the SRU (with penalties for deficiency). These dynamics are antagonistic in that the rise in the numbers of private dwellings in a municipality directly diminishes the municipal percentage of social housing. Indeed, in deficient municipalities, whose fabric is mostly of a suburban nature, local governments have limited operating power compared to the many private landlords in the suburbs. Such municipalities find themselves at an impasse, not having the land available, or the knowhow, to build enough social housing in order to offset the private housing multiplication and densification. It should be noted that the accustomed scale of collective social housing, which mobilizes the traditional public bodies of social housing (e.g., social landlords), is much larger than the plot of a suburban house. Furthermore, municipalities that are not deficient at the moment but have an important share of their territory susceptible to densification (i.e., suburban neighbourhoods) may find themselves deficient in the future if the imminent process of densification is not accompanied by a systematic social housing construction policy at the scale of the suburban private plot.

Therefore, what can be observed is an operating flexibility afforded to a multitude of private housing actors (landlords and developers) in contrast to the penalization of public actors with low operational power in the suburbs (municipal governments and social landlords). As a result, the operational feasibility of both of these policies in the same suburban territory is questioned.

Today in France, 56\% of the population lives in a detached or semi-detached suburban dwelling (INSEE, 2016), and a full $87 \%$ considers this the ideal type of housing (and therefore wishes or plans to live in such a house; Damon, 2017). At the same time, $74 \%$ of all French households are eligible to apply for social housing (INSEE, 2009), with four million people considered to have inadequate or no housing, and an estimated 12.1 million people affected by the housing crisis (Foundation Abbé Pierre, 2017). Could the popular suburban housing model play a role in social housing provisions? Are there ways of constructing small-scale social housing in the suburban fabric? What socio-political concepts are used for social housing, and are they relevant for the suburbs? 


\section{The engines of social housing production}

In the French Construction and Housing Code (Fr. Code de la Construction et de l'Habitation), Article L.411 defines the role of social housing in France: "The construction, development, attribution, and management of social rental housing aims to improve the housing conditions for people of moderate or low income. These operations participate in the implementation of the right to housing and contribute to the necessary social diversity of cities and neighbourhoods" (law no. 98-657 of 29 July 1998). These are the first phrases of volume four of the code titled Low-Income Housing (Fr. Habitations a loyer modéré), and they clearly highlight the two fundamental challenges of social housing in contemporary France: the right to housing and social diversity.

Indeed, the right to housing is the central idea that led almost all European countries to the large-scale construction of social housing after the Second World War (Scanlon et al., 2015). Having been identified as a fundamental human right (in the Universal Declaration of Human Rights signed in Paris in 1948), housing in western Europe "was seen as part of the social contract between government and citizens which made up the welfare state" (Scanlon et al., 2015: 2). In France, providing housing to those that are unable to access it has been a continuous preoccupation of the state with numerous laws and policies (Driant, 2015). In the 1990s, legal and political efforts concerning the right to housing again moved to the forefront. The right to housing is the subject of the 1990 Besson Law (law no. 90-449 of 31 May 1990), which establishes a new register for urban policies concerning housing, with a focus on the underprivileged population. This law introduces the PLAI (Fr. Prêt locatif aidé d'intégration 'Subsidised Rental Loan for Integration') category of social housing (a category focused specifically on the most vulnerable), and it makes citizens' associations important actors in the social housing sector (Driant, 2015; Stébé, 2016).

During the same period, within the official vocabulary of urban policies, a new term, social diversity, emerged (most notably with the laws of the 21 December in 1989, known as the "anti-ghetto law", and the "urban orientation law" of 1991; Driant, 2015). This concept is a response to the ghettoization of certain populations that tend to inhabit the social housing blocks. In order to address the socio-spatial segregation of the population and the socio-political division that it entails, the proposition of social diversity is that better distribution of social housing throughout French territory leads to diversification of the housing supply, and therefore to the social diversification of neighbourhoods (Lelévrier, 2014; Charmes \&
Bacqué, 2016c). The diversity envisioned refers to income levels and socio-professional categories, but also includes underlying ethnic, racial, cultural, and religious diversity (Charmes \& Bacqué, 2016a). The approach of this policy is of a spatial character, meaning that its logic is to bring different social groups together in the same places. It is an approach that crosses all government and urban planning scales, regional, municipal, and neighbourhood (Driant, 2015). The driving concept is that its application can change a certain percentage of the population of a neighbourhood, thereby increasing the value of its real estate, and that the spatial proximity of different social groups will cultivate social integration and cohesion (Lelévrier, 2014).

However, the research community has pointed to contradictory results between the two fundamental objectives of social housing (the right to housing and social diversity): the underprivileged population is most commonly housed in less expensive social housing, which is mostly found in working-class neighbourhoods, and this therefore yields contradicting results regarding the objectives of social diversity policies (Jaillet, 2011). The right to housing may have a certain ethical impact and a political value that are not questioned at the European scale or at the French national scale; in contrast, social diversity is a concept that is only applied by the French state at the national level (Houard, 2011; Scanlon et al., 2015; Dhoquois et al., 2016). The concept of social diversity has been widely contested in French literature due to the principles it is founded upon, its underlying objectives, its application strategies, and its socio-political effects on the territory (Lelévrier, 2014; Driant, 2015; Charmes \& Bacqué, 2016c; Stébé, 2016).

\section{Social diversity: a contested concept}

Since its inception, social diversity has been an effective political concept due to its "plastic character" (Jaillet, 2011: 351), which is due to "the notion's polysemy and the diversity of interpretations that could be drawn from it. This polysemy favours a sort of consensus and legitimizes policies that could be vastly different from one another," as supported by Charmes and Bacqué (2016a: 12). They refer to two distinct policies that are both implemented in the name of social diversity but are nearly opposites of each other. One approach is to demolish collective social housing in working-class neighbourhoods in order to replace the housing supply with a more diverse one, thus profiting middle-class households. The other approach is to construct social housing in middle- and upper-class neighbourhoods. These are two sides of the same coin. In his work, Driant specifies these two approaches in France (2015):

- One side of the coin is the policy of urban renovation. 
This policy promotes processes of demolition and reconstruction to improve the image and attractiveness of underprivileged neighbourhoods by replacing social housing with a housing supply more attractive to middle - income brackets of the population. However, numerous researchers agree that the spatial proximity of households with different incomes does not negate social distance (on the contrary, it could reinforce it), and it certainly does not resolve social, financial, and political inequalities (Jaillet, 2011 Lelévrier, 2014; Driant, 2015; Giroud, 2016; Stébé, 2016). Such processes of urban renovation (demolition and reconstruction) are mostly carried out in areas with collective social housing that are well situated in relation to urban centres (or at least well connected to them) in order to generate attractiveness and surplus value by offering "an alternative to homeownership in the suburban" environment, with dwellings that are affordable "without having to move to the periphery" (Lelévrier, 2014: 118).

- The other side of the coin is none other than the imposition of a minimum quota of social housing within the total housing stock of municipalities (the infamous Article 55 of the SRU in 2000, and the subsequent Duflot Law 2013). If urban renovation policies are considered to offer an alternative to peri-urban housing, then the SRU could be considered highly pertinent to peri-urban territory. The SRU has had an important influence on social housing production in deficient municipalities, with an increase of 12.7\% between 1999 and 2011 (compared to the $6 \%$ increase in non-deficient municipalities), translating into an increase in new social housing units from 87,000 in 2002-2004 to an estimated of 140,000 in 2011 - 2013 (Vie publique, 2014; Ministère de la Cohésion ... , 2015). In contrast, in the region of Provence-Alps-Cote-d'Azur (where nearly 40\% of deficient municipalities of France are found), an increase in deficient municipalities has been noted since 2008, attributed to population growth and therefore an increase in private dwellings (Boullion \& Couartou, 2016). This serves as an initial indication of the importance of suburbs in this discussion because private dwellings in France are mostly of a suburban nature. Stébé (2016: 115) states that "city centres have proven to follow proactive policies," achieving a higher social housing quota than demanded, whereas municipalities identified as "low performing" are found in the peri-urban areas of large urban centres, and / or are municipalities with a mostly suburban fabric. According to a national survey on Article 55 of the SRU, the municipalities that paid the highest fines in 2016 were Saint-Maur-des-Fossés, Neuilly - surSeine, Le Cannet, Sanary-sur-Mer, and Grasse (Ministère de la Cohésion ..., 2016). Four out of five of these municipalities have a significant share of suburban fabric, and the fifth (Neuilly-sur-Seine is the only one without a suburban character) is found in the Paris peri-urban area (Google Maps, 2017). This is yet another indication that the obligations prescribed by the SRU pose problems for suburban and peri-urban communities. However, the following question still remains: Does the political justification of social diversity (imposed on the territory through Article 55 of the SRU) provide a valid discourse for suburban and peri-urban communities?

\section{The importance of social diversity for the peri-urban area}

The peri-urban area in France has become synonymous with suburban development, and it is a territory commonly accused of having socioeconomic homogeny, lacking architectural and urban qualities, and plagued by its monofunctionality. Although the architectural and functional homogeny is not contested, the work of researchers such as Dodier et al., Anne Lambert, and Charmes (among others) clearly demonstrates the socioeconomic and political diversity of the French peri-urban area.

"There is not one but several peri-urbans" (Charmes et al., 2016: 85), and each of these peri-urban areas varies in its attributes, and their populations have diverse characteristics and political orientations. While admitting a social diversity "slightly weaker than found in the urban space" (the wealthiest and most impoverished social classes being less present), Dodier $(2007: 35$-46) draws attention to the presence of all social categories in the peri-urban areas and invites consideration of a more detailed geography and sociology of suburban territory. Even within each of these peri-urban areas, it is possible to discover a plurality of ways of living and the residents' relations to the neighbourhood and the city - aspects that depend on gender, age, ease of transport, and so on (Cailly \& Dodier, 2007). Within all of these variations, certain discrimination has also been identified based on class, nationality, ethnic or racial background, gender, and so on (Lambert, 2015). All of these elements highlight the important social diversity of the peri-urban areas and provide motivation to surpass the polarization between urban and peri-urban areas. They demonstrate the importance of "focusing tirelessly on the context and in particular the inequalities between neighbourhoods and the social differentiations" (Sampson, 2016: 35), which is Sampson's most fundamental advice for socio-urban research.

As described above, public policies promoting social diversity are founded on a spatial approach. For the peri-urban areas that Dodier studied on the periphery of the cities of Tours and Le Mans, certain socioeconomic variations were identified 
to correlate with a "spatial differentiation" composed of three main elements. The first involves the distance from the urban centre in concentric circles. This is a constant and converging observation between researchers, with the value of houses and land, and thus the socioeconomic level of the residents, decreasing progressively and in a fairly systematic manner depending on the distance from the city centre (Cailly \& Dodier, 2007; Dodier, 2007; Jaillet, 2011; Driant, 2015). Second, there is a differentiation that correlates with the quadrants around the city (north, east, south, and west), showing different development dynamics related to the specific features of the territory (e.g., landscape quality, location in relation to public infrastructure such as public transport, and proximity to work areas). The third spatial differentiation that causes socioeconomic variations depends on real-estate fragmentation and is specific and internal to each case (e.g., plot size and date of construction; Cailly \& Dodier, 2007).

Through this detailed socio-spatial analysis, and through recognizing the importance of context in each case (Sampson, 2016), the scale of the municipality and of $a$ peri-urban area is specified and analysed at the more detailed scale of the neighbourhood and several peri-urban realities existing within what was previous conceived as one homogenous territory. At this detailed scale, it is possible to arrive at a deeper understanding of each neighbourhood of the peri-urban areas, and thus it is possible to arrive at a reading of true homogeny, where it exists. Thus, social diversity could be a relevant concept for the suburbs. Interestingly, Sampson was also one of the members of the national advisory committee for the ambitious social experiment called the Moving to Opportunity for Fair Housing Demonstration Programme (Briggs et al., 2010). In the United States in the 1990s, this programme studied neighbourhood effects on low-income households, helping such families move from high-poverty areas to lower-poverty areas, most of them in the suburbs (Briggs et al., 2010; Ludwig, 2012). Although this programme has been criticized for political naivety (Geronimus \& Thompson, 2004), most studies point toward important positive effects, including housing conditions (Briggs et al., 2010), education, employment, and delinquency (Gennetian et al., 2012), economic gains (Chetty \& Hendren, 2015), and health (Ludwig et al., 2011) of the low-income families that were relocated. Consequently, there are indications that an urban policy of social diversity may find fertile ground in suburban territories.

\section{Social housing as a bearer of social diversity in the French suburbs?}

With regard to the French suburbs, it can be established that "in the first peri-urban concentric circle of large cities, the social situations are globally more specific, being middle-class" (Dodier, 2007: 35-46) and tending toward upper-class socioeconomic status. These types of peri-urban areas are typically neighbourhoods built in the 1960s, when the popularization of private cars and various urban policies promoted diffused urbanization (Callen, 2011; Haëntjens, 2011; Magri, 2015), with many of their quadrants characterized by suburban houses on large plots, which are usually well-served by public infrastructure (e.g., schools and hospitals), well connected through public transport to the city centre and thus to work areas, and so on (Dodier \& Cailly, 2008; Desgrandchamps et al., 2010; Petitet, 2013). These characteristics of urban fabric and location provide favourable conditions both for densification processes (e.g., large plots and good service) as much as for social housing construction (e.g., public transport and work area proximity; Desgrandchamps et al., 2010; Petitet, 2013; Touati \& Crozy, 2015). In addition, the fact that the socioeconomic groups that inhabit these neighbourhoods are mostly middle to upper class means that social diversity policies through social housing construction find ethically less conflicting legitimization while still fulfilling the other fundamental role of social housing (as defined in the French Construction and Housing Code): providing housing for disadvantaged households. Therefore, within many quadrants of the first concentric circles of peri-urban areas, potentially fruitful ground is being discovered for the productive intersection of suburban elements (and their densification) and social housing (and therefore social diversity), while constantly taking care to avoid generalizations. This includes paying attention to the context and specific social, economic, and political characteristics of each neighbourhood, and to quadrant aspects such as real-estate fragmentation, landscape quality, sizes of plots, dates of construction, and so on.

Today in France's peri-urban areas there are examples of successful social housing construction at the scale of the private plot. In particular, there are a number of associations (or "social micro-landlords") that systematically produce defused, smallscale social housing projects (one to twelve units per project) within suburban densification procedures (Primard \& Touati, 2015). These actors produce PLAI social housing for the most vulnerable, and one of the necessary conditions for commencing a project is the location and its proximity to amenities (e.g., transport, commerce, schools, and work areas). The associations function within the legal framework provided by the Besson Law (profiting from both their possible role within the social housing market and the PLAI category of social housing). In most cases, PLAI social housing already constitutes a form of social diversity for the suburban area; however these social micro-landlords make an additional effort to integrate student housing, housing for seniors, or intergenerational housing (all recognized as social housing by the 
SRU) within their projects when such housing is considered pertinent to the wider urban context and the local housing policies. In addition, there is an effort to promote social diversity within each project, with residents of different ages, revenue levels, and so on chosen for small collective housing projects. Finally, when Étienne Primard (the co-founder and president of such an association, Solidarités nouvelles pour le logement 'New Solidarities for Housing', or SNL) was asked in an interview about the most essential criteria for launching a project, the first one he highlighted is the possibility of mobilizing neighbours in participatory procedures related to the project (Primard \& Touati, 2015).

Indeed, with efforts to construct social housing in the suburban densification context of middle- and upper-class peri-urban areas, the concept of social diversity is bound to face opposition from residents. Although social diversity is an idea well accepted by the majority of the French population (ELABE, 2016), suburban densification is almost always met with discontent from local residents (Desgrandchamps et al., 2010) and the reputation of social housing only adds to that tension. Participatory processes are a way to discuss and adjust a project in order to achieve its construction while providing satisfactory solutions to all interested actors. These types of project procedures contribute to new trades, new practices, and new abilities in the urban fabric (Biau et al., 2013). The detailed analysis by Dodier and the deeper understanding of peri-urban areas, as much as the attention to context and the progress from the terrain sociology of Sampson, promote a form of citizen participation in the sense of the importance given to the inhabitants' word. Increasingly, these participatory approaches are considered necessary elements of suburban densification processes (Petitet, 2013; Hanrot, 2015). In social housing, resident consultation and participation are already an integral part of social housing management (Demoulin, 2013; Dhoquois, 2016), and in recent years Patrick Bouchain (2010, 2016), an architect celebrated for his participatory project methods, has examined the possibilities of inhabitant participation in the conception and construction of social housing. Even for contested and questioned urban policies of social diversity, the criticism is that they "are unfortunately often carried out without, and in some cases against, the concerned inhabitants" (Charmes \& Bacqué, 2016b: 99-100). Furthermore, the potential of a participatory social diversity policy, through procedures that respect the existing residents and create true social connections between old and new residents, is often highlighted (Lelévrier, 2014; Charmes \& Bacqué, 2016c).

It is important not to conceal the great complexity of participatory processes in the urban project, not to consider it a panacea for all urban problems. In thirty years of the experience of the SNL association in such a tense and conflict-rid- den area, they have never had a construction permit blocked by residents (Touati, 2014), and so their model of operation could at least serve as a source of inspiration. With their projects well accepted by both local governments (because they contribute to lowering the fines related to the SRU) and local residents (because they are informed and can influence the result through their participation - a result that always remains on the architectural scale of the suburban), the SNL model serves as a successful example. It is crucial to learn from such an example, specifically by following Primard's advice on resident consultation and participation throughout all planning scales, whether this is regional (and includes the formulation of regional planning documents such as the SCoT or the PLH in the French case), or at the scale of the municipality and its neighbourhoods (with planning documents such as the local urbanism plans; Primard \& Touati, 2015). At the same time, it is equally important to note its weaknesses:

- These associations are based on a certain political commitment of their founders, related to the right to housing of their fellow citizens, and the great majority of their personnel are volunteers (in the case of the SNL, $70 \mathrm{em}$ ployees and 1,127 volunteers; SNL-Union, 2017).

- Furthermore, this method of producing social housing within suburban densification processes will continue to remain marginal if it does not include financial interests for private landlords (the owners of the vast majority of suburban land).

In order to achieve the popularization of such an urban policy and make the diffused production of social housing systematic at the suburban scale, it is necessary to consider the reality of densification that is bound to be mostly at the scale of the private suburban plot and initiated by private landlords, and must therefore offer a certain financial compensation to the owner.

\section{Conclusion}

Beyond committed associations, there are other actors interested in this subject, actors that must be mobilized in the effort to provide solutions. First of all, the municipalities have an interest in finding ways to avoid the SRU fines they are currently paying while providing housing through suburban densification. Furthermore, the traditional bodies of social housing (social landlords) must also be mobilized. During the last decade, these social landlords have become increasingly interested in smaller project scales (with 95\% of constructed social housing being small collective housing complexes, intermediary housing, or individual dwellings; Stébé, 2016). Their collaboration with private developers and constructors is becoming more common, and thus easier and simpler with time (Dhoquois, 2016). In addition, these traditional social 
landlords have also started committing to projects with a more urban design / renewal character by including public spaces, shops, and other places (Couartou, 2016). With the hypothesis of the commitment of these social landlords / urban designers in the suburban context, the beginning of an urban, architectural, and functional diversity is possible to imagine.

Although social diversity is a contested concept, in certain contexts it could be a beneficial policy objective. Questioning popular belief, the social characteristics of the French suburbs have proven to be rather diverse. However, by following an in-depth, detailed analysis of peri-urban areas, and by focusing on the context of each case, it is possible to find examples where social diversity policies could be productive. International cases provide an encouraging basis to inspire such diversity experimentations, focusing on suburban fabric in the first peri-urban circle.

Furthermore, the example of social micro-landlords, such as the SNL, could effectively serve as operating models for these actors (such as the municipalities themselves and the traditional social landlords). What their model indicates is that participatory procedures could help reconcile the antagonism between private and social housing dynamics through collaboration between inhabitants, municipalities, and social landlords, and the mobilization of private dwellings in social housing provisions. However, there is currently no regulatory apparatus that could clearly and easily bring inhabitants, municipalities, and social landlords (whether micro-landlord, traditional landlord, or landlord as urban designer) together in construction operations. Moreover, the need for solutions that are financially more attractive for more of the actors involved demands thorough reflection. Urban, architectural, and landscape proposals that respond to the environmental objective of densification, and at the same time respond to the social objective of social housing, must be provided. The ensemble of these reflections on the subject must take into account all levels, starting from the level of the EU and its urban policies, to the national, regional, municipal, and neighbourhood levels, and finally the level of the residents and their private plots. The proposals should be produced through participatory procedures in order to offer solutions that are socially, politically, financially, and architecturally viable, enduring, and sustainable for peri-urban environments of the future.

\section{Ion Maleas}

Marseilles School of Architecture, Marseille, France

E-mail: ionmaleas@gmail.com

\section{Acknowledgments}

This article was supported through a doctoral scholarship from the Ministry of Culture and Communication of France. I would also like to express my gratitude to Stéphane Hanrot, ENSA-Marseille, and Jérôme Dubois, IUAR, for their guidance.

\section{References}

Biau, V., Fenker, M. \& Macaire, E. (eds.) (2013) Limplication des habitants dans la fabrication de la ville: métiers et pratiques en question. Paris, Éditions de la Villete - Reseau RAMAU.

Bonnet, F. (2016) Aménager les territoires ruraux et périurbains. Available at: http://www.ladocumentationfrancaise.fr/var/storage/rapports-publics/164000021.pdf (accessed 26 Apr. 2017).

Bouchain, P. (2010) Construire ensemble le grand ensemble. Arles, Actes Sud.

Bouchain, P. (2016) Pas de toit sans toi: réinventer l'habitat social. Arles, Actes Sud.

Boullion, S. \& Couartou, M. (2016) Refuser la constitution de ghettos, de pauvres comme de riches. In: Dhoquois, A. (ed.) HLM: changeons notre regard! Loger social pour développer local en Provence-Alpes-Côte d'Azur et Corse, pp. 122-125. Paris, Éditions Autrement.

Briggs, X. S, Popkin, S. J. \& Goering, J. (2010) Moving to opportunity: the story of an American experiment to fight ghetto poverty. New York, Oxford University Press. DOI: 10.1093/acprof:oso/9780195393712.001.0001

Cailly, L. \& Dodier, R. (2007) La diversité des modes d'habiter des périurbains dans les villes intermédiaires: différenciations sociales, démographiques et de genre, pp. 66-80. Norois-Poitiers, Universités de l'Ouest.

Callen, D. (2011) La "fabrique péri-urbaine", système d'acteurs et production des ensembles pavillonnaires dans la Grande Couronne francilienne. Doctoral thesis. Paris, Université Paris 1 Panthéon-Sorbonne. Available at: https://hal.archives-ouvertes.fr/tel-00651441/document (accessed 30 Aug. 2017).

Charmes, E. (2015a) La ville émergente. Available at: http://www.citego org/bdf_fiche-document-25_en.html (accessed 18 Feb. 2018).

Charmes, E. (2015b) L'entre ville. Available at: http://www.citego.org/ bdf_fiche-document-24_en.html (accessed 18 Feb. 2018).

Charmes, E. \& Bacqué, M. H. (2016a) Au-delà de l'impératif de mixité social. In: Charmes, E., \& Bacqué, M. H. (eds.) Mixité sociale et après? pp. 7-14. Paris, Presses Universitaires de France.

Charmes, E. \& Bacqué, M. H. (2016b) Conclusion. In: Charmes, E. \& Bacqué, M. H. (eds.) Mixité sociale et après? pp. 125-143. Paris, Presses Universitaires de France.

Charmes, E. \& Bacqué, M. H. (eds.) (2016c) Mixité sociale et après? Paris, Presses Universitaires de France. DOI: 10.3917/popu.1703.0552

Charmes, E., Launay, L. \& Vermeersch, S. (2016) Le périurbain n'est pas une version dégradée de la ville. In: Charmes, E. \& Bacqué, M. H. (eds.) Mixité sociale et après? pp. 81-96. Paris, Presses Universitaires de France.

Chetty, R., \& Hendren, N. (2015) The impacts of neighborhoods on intergenerational mobility: Childhood exposure effects and county-level estimates. Available at: https://scholar.harvard.edu/files/hendren/files/ nbhds_paper.pdf (accessed 18 Feb. 2018).

Couartou, M. (2016) Quand les HLM aménagent l'espace urbain. In: Dhoquois, A. (ed.) HLM: changeons notre regard! Loger social pour développer local en Provence-Alpes-Côte d'Azur et Corse, pp. 114-117. Paris, Éditions Autrement. 
Crysler, C. G., Cairns, S. \& Heynen, H. (eds.) (2012) The Sage handbook of architectural theory. London, Sage.

Damon, J. (2017) Les Français et l'habitat individuel: préférences révélées et déclarées. SociologieS. Available at: https://sociologies. revues.org/5886 (accessed 26 Apr. 2017).

Demoulin, J. (2013) Les organismes HLM et leur personnel face à la participation des locataires. In: Biau, V., Fenker, M. \& Macaire, E. (eds.) L'implication des habitants dans la fabrication de la ville: métiers et pratiques en question, pp. 55-70. Paris, Éditions de la Villete - Reseau RAMAU.

Desgrandchamps, G., Ferrand, M., Léger, J. M., Le Roy, B. \& Le Roy, M. (2010) Lotir les lotissements: conditions architecturales, urbanistiques et sociologiques de la densification douce de l'habitat individual. In: Bendimérad, S. (ed.) Habitat Pluriel densité urbanité intimité, pp. 117-138. Paris, PUCA.

Dhoquois, A. (ed.) (2016) HLM: changeons notre regard! Loger social pour développer local en Provence-Alpes-Côte d'Azur et Corse. Paris, Éditions Autrement.

Dhoquois, A., Oliviero, P. \& Ghékière, L., (2016) L'avenir du mouvement HLM dans le contexte européen. In: Dhoquois, A. (ed.) HLM: changeons notre regard! Loger social pour développer local en Provence-AlpesCôte d'Azur et Corse, pp. 122-125. Paris, Éditions Autrement.

Dodier, R. (2007) Quelle articulation entre identité campagnarde et identité urbaine dans les ménages périurbains? Norois-Poiters, Universités de I'Ouest.

Dodier, R. \& Cailly, L. (2008) La diversité des modes d'habiter des périurbains dans les villes intermédiaires: differenciations sociales, démographiques et de genre. Norois-Poiters, Universités de l'Ouest.

Donzelot, J. \& Epstein, R. (2009) La ville à trois vitesses et autres essais. Paris, Editions de la Villette.

Driant, J. C. (2015) Les politiques du logement en France. Paris, La Documentation Française.

Duany, A., Plater-Zyberk, E. \& Speck, J. (2010) Suburban nation: The rise of sprawl and the decline of the American dream. New York, North Point Press.

Dubois-Taine, G. \& Chalas, Y. (1997) La Ville émergente. Tour-d'Aigues, Éditions de l'Aube.

ELABE (2016) Les français, le logement social et la mixité. Available at: https://elabe.fr/wp-content/uploads/2016/04/ELABE_ALILA_Etude_Egalite_Citoyennet\%C3\%A9.pdf (accessed 26 Apr. 2017).

Fishman, R. (1987) Bourgeois utopias: The rise and fall of suburbia. New York, Basic Books.

Foundation Abbé Pierre (2017) 22e rapport sur l'état du mal-logement en France 2017. Available at: http://www.fondation-abbe-pierre.fr/22e-rapport-etat-mal-logement-en-france-2017 (accessed 26 Apr. 2017).

Gennetian, L. A., Sciandra, M., Sanbonmatsu, L., Ludwig, J., Katz, L. F., Duncan G. J., et al. (2012) The long-term effects of moving to opportunity on youth outcomes. Cityscape: Moving to Opportunity, 14(2), pp. 137-167.

Geronimus, A. T. \& Thompson, J. P. (2004) To denigrate, ignore, or disrupt: Racial inequality in health and the impact of a policy-induced breakdown of African American communities. Du Bois Review: Social Science Research on Race, 2, pp. 247-279. DOI: 10.1017/ S1742058X04042031

Giroud, M. (2016) Mixité, contrôle social et gentrification. In: Charmes, E. \& Bacqué, M. H. (eds.) Mixité sociale et après? pp. 49-64. Paris, Presses Universitaires de France.
Google Maps (2017) Satellite images of municipalities: Saint-Maur-desFossés, Neuilly-sur-Seine, Le Cannet, Sanary-sur-Mer, Grasse. Available at: https://www.google.com/maps/ (accessed 26 Apr. 2017).

Haëntjens, J. (2011) La ville frugale; un modèle pour préparer l'après pétrole. Paris, FYP éditeur.

Hanrot, S. (2014) Densifier le pavillonnaire: des principes à la réalité. Available at: http://mixcite.caue74.fr/wp-content/uploads/2014/12/journal_expo_construire_dans_mon_jardin.pdf (accessed 14 Apr. 2018).

Hanrot, S. (2015) Pour une stratégie de projet urbain participatif dans les quartiers pavillonnaires. In: Touati, A. \& Crozy, J. (eds.) La densification résidentielle au service du renouvellement urbain: filières, stratégies et outils. Paris, La Documentation Française.

Houard, N. (ed.) (2011) Loger l'Europe: le logement social dans tous ses États. Paris, La Documentation Française.

Indovina, F. (1990) La città diffusa. Venice, Istituto universitario di architettura.

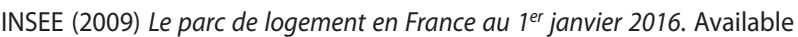
at: https://www.insee.fr/fr/statistiques/2533533 (accessed 26 Apr. 2017).

INSEE (2016) 74\% des ménages éligibles au logement social - Logement 2006. Available at: https://www.insee.fr/fr/statistiques/1290403 (accessed 26 Apr. 2017).

INSEE (2017) Base comparateur de territories. Available at: https://www. insee.fr/fr/statistiques/2521169 (accessed 26 Apr. 2017).

Jackson, K. T. (1985) Crabgrass frontier: The suburbanization of the United States. New York, Oxford University Press.

Jaillet, M. C. (2011). La mixité dans les politiques françaises du logement: une question sensible. In: Houard, N. (ed.) Loger l'Europe: le logement social dans tous ses États, pp. 343-360. Paris, La Documentation Française.

Lambert, A. (2015) "Tous propriétaires!" L'envers du décor pavillonnaire. Paris, Seuil.

Lelévrier, C. (2014) Diversification de I'habitat. Lyon, Plan Urbanisme Construction Architecture.

Lévy, J. (2007) Regarder, voir. Un discours i formé par la cartographie. Les annals de las recherche urbaine, 102, pp. 131-140. DOI: 10.3406/ aru.2007.2702

Ludwig, J. (2012) Guest editor's introduction. Cityscape: Moving to Opportunity, 14(2), pp. 1-28.

Ludwig, J., Sanbonmatsu, L., Gennetian, L. A., Adam, E., Duncan, G. J., Katz, L. F., et al. (2011) Neighborhoods, obesity, and diabetes - A randomized social experiment. New England Journal of Medicine, 265(16), pp. 1509-1519. DOI: 10.1056/NEJMsa1103216

Magri, S. (2015) L'habitat pavillonnaire à rebours des idées reçues. Métropolitiques. Available at: http://www.metropolitiques.eu/L-habitat-pavillonnaire-a-rebours.html (accessed 29 Aug. 2017).

Ministère de la Cohésion des Territoires (2015) Le bilan triennial 2011 2013 de la loi SRU. Available at: http://www.cohesion-territoires.gouv. fr/IMG/pdf/150315 sp_annexe_bilan_triennal_sru_2011-2013.pdf (accessed 17 Feb. 2018)

Ministère de la Cohésion des Territoires (2016) Bilan 2016 de l'article 55 de la loi SRU (excel). Available at: http://www.cohesion-territoires.gouv. fr/transparence-logement-social\#article (accessed 26 Apr. 2017).

Ministère de la Cohésion des Territoires (2018) Transparence logement social. Available at: http://www.cohesion-territoires.gouv.fr/transparence-logement-social\#article (accessed 17 Feb. 2018). 
Ministère du Logement et de l'Égalité des territoires (2014) Lutte contre l'étalement urbain. Available at: http://www.cohesion-territoires. gouv.fr/IMG/pdf/alur_fiche_lutte_contre_I_etalement_urbain.pdf (accessed 26 Apr. 2017).

Petitet, S. (2013) Densifier l'habitat pavillonnaire: des démarches individuelles aux projets collectifs. Métropolitiques. Available at: http:// www.metropolitiques.eu/Densifier-I-habitat-pavillonnaire.html (accessed 26 Apr. 2017).

Primard, E. \& Touati, A. (2015) La construction de logements sociaux en densification douce par les micro-bailleurs: le cas de Solidarités Nouvelles pour le Logement. In: Touati, A. \& Crozy, J. (eds.) La densification résidentielle au service du renouvellement urbain: filières, stratégies et outils. Paris, La Documentation Française.

PUCA (2015a) Du périurbain à l'urbain (2011-2013). Available at: http:// www.urbanisme-puca.gouv.fr/du-periurbain-a-l-urbain-2011-2013-a479. html (accessed 17 Feb. 2018).

PUCA (2015b) La mobilité et le périurbain à l'impératif de la ville durable: ménager les territoires de vie des périurbains (2009-2014). Available at: http://www.urbanisme-puca.gouv.fr/la-mobilite-et-le-periurbain-a-l-imperatif-de-la-a246.html (accessed 17 Feb. 2018).

PUCA (2015c) Territoire et développement durable (2003-2010). Available at: http://www.urbanisme-puca.gouv.fr/territoire-et-developpement-durable-2003-2010-a264.html (accessed 17 Feb. 2018).

Sampson, R. (2016) Une théorie des effets de quartier et du contexte social. In: Charmes, E. \& Bacqué, M. H. (eds.) Mixité sociale et après? pp. 31-47. Paris, Presses Universitaires de France.

Scanlon, K., Fernàndez, A. M., \& Whitehead, C. (2015) Social housing in Europe. European Policy Analysis, 17, pp. 1-12.

Sieverts, T. (2003) Cities without cities: An interpretation of the Zwischenstadt. London, Spon Press. DOI: 10.4324/9780203380581

SNL-Union (2017) Présentation. Available at: https://www.snl-union.org/ nous-connaitre/presentation/ (accessed 26 Apr. 2017).

Stébé, J. M. (2016) Le logement social en France. Paris, Presses Universitaires de France.

Touati, A. (ed.) (2014) Vers des politiques publiques de densification et d'intensification douces? Paris, Séminaire PUCA.

Touati, A. \& Crozy, J. (eds.) (2015) La densification résidentielle au service du renouvellement urbain: filières, stratégies et outils. Paris, La Documentation Française.

Vie publique (2014) Logement social: l'impact de la loi SRU. Available at: http://www.vie-publique.fr/actualite/alaune/logement-social-impact-loisru-20141230.html (accessed 18 Feb. 2018). 